\title{
Communication on the difficult route of lie
}

\author{
Ştefan Vlăduţescu \\ University of Craiova, 13 A. I. Cuza Street, 200585, Craiova, Romania \\ E-mail address: stefan.vladutescu@yahoo.com
}

\section{ABSTRACT}

The study explores de phenomenon of deception. It proves that 1 s a nunic ions with fictional content focused on the expectations of a person or social group and aim à blema cituation. The untrue communicative instance lacks figure: nobody is de a liar th they lie. The productions do not have a producer presenting itself as a liar, bu $t$ is a vs empha, ised by a certain recipient. They have a content related to the current cognitive cical in ts of the target. The liar acts in two directions: by distorting a correct thinking, by erverting the lan ge. It is a man lacking
language responsibility and a profiteer of cogitation.

Keywords: communication; fiction; persuasion; lie

\section{INTRODUCTION}

In the dictionary Laraus. $\mathrm{sl}$

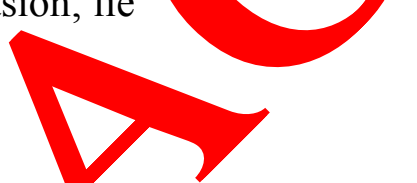
contrary to the truth". In te Lxpla sry Dictionary of Romanian Language, the lie is seen as a deliberate distortion th, usuan thed to deceive someone. The synonyms of the term "lie" would be: un th, it, wile) dissimulation, simulation, duplicity etc. The idea of untruth in the sen fie, his encounters it for the first time in the European culture in Iliad by Homer. In sook X of the H meric description, Achilles moralises: "I hate that man like

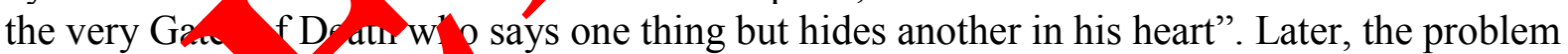
of the untruth ebated y Plato in Hippias Minor; here, the idea of language falseness, show is the is a force in relation to its object. In its turn, the liar gains power by pro ting he lie: "to false are strong and prudent and skilled and prudent with those things in re they are fake". Thinking the lie as immoral enterprise is also encountered at St. A stine in De Mendacio. He shows that a "lie is the deliberate expression of a clear untruth" (4 Steiner, 1983, p. 266).

\section{TRUTH AND REALITY}

"Philosophers of suspicion" (as Paul Ricœur calls Nietzsche, Marx and Freud) have the problematic of truth in their preoccupations. Inertially, they are forced towards thinking about lie exactly through this. Of the three, Friedrich Nietzsche is the one that raises most radically the problem of the truth-lie ratio. "What is the truth?" he wonders in "On Truth and Lies in an 
Extra-moral Sense" (Nietzsche, 1998, p. 45): the truth is "a moving army of metaphors, metonymies, anthropomorphisms, in short an assembly of human relations which have been poetically and rhetorically reasoned, transformed and made more gladsome: (...) the truths are illusions which it has been forgotten they would be such a thing. What we consider to be true represents an illusion which we do not remember as illusion and which consists of metaphors. "We possess nothing but metaphors of things" (Nietzsche, 1998, p. 39).

All beings are beneath underlie illusions and metaphors, and what distinguishes man from the animal depends on this faculty of dissolving the intuitive metaphors in a scheme, meaning to bring an image to the concept. "The world seems logical to us, because whave made it logical", shows Nietzsche in The Will to Power, aphorism 521 (Nietzs rie, 200 287). Admitting that we could however reach the truth in the world of metapho in this wo made logical, Nietzsche wonders what would truth be necessary for. We fin the wer in tl extra-moral "On Truth and Lies in an Extra-moral Sense".

The truth is necessary in terms of the indications provided to us vits $f$ tion oring liberation to man, therefore freedom (Avrigean, 2009; Bok, 2011 Bo 2013; Borowski, 2014). The truth liberates. It imposes the m e difficu as $j / 1$ already settled on a false truth. The system of metaphors was crowner a a ique valio ay to describe the world. There however remains an existing possibility: to listing between the man who honestly tells the truth and the liar who hides it. "Th 1 and no ctruth - is divine!", exclaims Nietzsche (Apud Steiner, 1983, p. 269). Seg ing the truth is dgne by lying. Nietzsche states that "The liar uses the valid designations, the ords, to ma"e the unreal appear as real; he says, for example, "I am rich", when the word " $p$ " would te the correct designation for his situation (Nietzsche, 1998, p. 33). Berides disto reality, the liar also distorts language: "he abuses the fixed conventions changes or even by reversals of the names" (Nietzsche, 1998, p. 33). Consequent , the ch in two directions: by distorting a correct thinking, by perverting the lanouage. It a man lacking language responsibility and a profiteer of cogitation. For Nietz che, truth is othing but a language obligation. The human subject is responsible for lang and thinking

The liar is a liar in fon and seeing this, the only punishment the society gives him is to cease to "st him". lie is no longer moral or immoral, but "extra-moral". The liar is extra-mor 1 bo se he is Jy oxcluded and because he is excluded only when he becomes harmful Thulie is al to the point where it harms, becoming extra-moral from that point onwards 1 his statute of lie fixes and enables an undeniable reality to it: "Thereby men do not fl from ing decelved as much as from being damaged by deception" (Nietzsche, 1998, p. 33). extra-n ral sense, the lie is unavoidable. In The Will to Power (aphorism 493), aficat is gi en on truth in its relation to a certain type of lie called error: "Truth is th kind f error yout which a certain species of life could not live" (Nietzsche, 2000, p. 240

criterion of truth is its value for life, and not the adherence to reality. Man feels morally o to tell the truth or to lie according to a convention set forth to the extent where one or anomer of the options is functional for the existence of society. The truth should be extra-moral, because people have the right to lie: "Neither Manu nor Plato nor Confucius nor the Jewish and Christian teachers have ever doubted their right to lie", he concludes in the Twilight of the Idols (Nietzsche F., 1994, p. 491). For Nietzsche, the truth and the lie are mutually supportive. When both fall, nihilism remains. Denying the truth by lying, denying then the truth and the lie, nihilism is reache. A cause of the lie would be the impulsiveness and deterioration of the feeling of truth (Avrigean, 2009; Bok, 2011; Botezat, Oprea \& Iliescu, 2013; Borowski, 2014). 
The dissimulations and simulations result from here. At other times, the lies are the result of a "single mental state of automatism, similar to that of somnambulism" which goes until autosuggestion. Lies also result from the need to know and influence the environment, to be in the centre of attention (Lombroso C, 1992, pp. 119-123). This content-message is supported by a speech structured on ideas in the very vicinity of what the target would like to know in relation to triggering or solving certain problematic situations. Sometimes, the target of a lie may be the producer himself. Through lie and untruth, he can more easily face the reality and the time he relates to. "Man likes to lie and be lied to and when nobody and nothing lies to him anymore, he is disaggregated" (Tudor Arghezi). In this case, the lie becomes protectima and therapeutic. The self-lying overlaps the almost natural tendency to reject all that co ntradic . inner balance. Isn't the medicine of the lie also a form of persuasion, jus te publici psychotherapy, suggestion, hypnosis, etc.?

Placing the object of speech in the vicinity of social representation in the targ sce pe of expectation represents the specificity of formulation and formula the thless cech. That its accessing occurs on a narrow range, at the boundary be ve posit ely selfachievable fiction and problematic reality, it provides it with the oower on emi ation.

The fictionality of lie is not in the fiction which it erically st orted on, nor especially in manipulation that is implicitly achieved, al ough h discursive sequences appear in truthless formulations. It is in the distortions ing the $\mathrm{n}$ ge: amplification of proportions, dramatisation, redefinition of prejy lices, distortion of meanings, overdevelopment of details, emotional recycling, compli ce with men alities. All these techniques are permanently adapted to the human-target segm s. The v ry co-participation of these targets provides credibility and efficiency to the lie. At lies are "made" of those who believe in them. This is why in the act of auditor's conscious or unconscious predisposition to lie is exploited. The liar's spe ch ms impeccable (congruent, logical, consistent, plausible, etc.). Lie does not arise 1 an empty land. It is expected and adulated, enjoying the co-participation.

"The liar is a well-situ ma shows C. Cucoş (Cucoş, 2002, p. 21). The lie is a cultural acquisition of an via ung into the community and has certain interests. The lying subject may and indiv lying for himself or on behalf of an entire group or, when it is a matter $Q^{f}$ pub relations, $n$ behalf of an institution. He always reasons not only in favour of a fictive cality, also in favour of fiction itself. The liar keeps the sizes of his interested ficti $n$ as real for thers, even under the pressure of his speech qualifying as truthless. Ac Ton shows (Tonoiu V., 1995, p. 243), he "destroys the reciprocity even when he seems stablish . He uses language against his normal vocation for communication and int ces in rela on to another an unevenness denying the ethical alterity, induces the obje tifyin devalua on and solitude. By setting on the guillotine of lie, the lying subject der hi most percussive one, almost lethal, is prov to him the social structure itself for free: it is a matter of the institutional-reflex lack of orienta cowards inspection. In society, the intention situations are always misleading, whichever ne appearances would be.

The truthless speech is woven as any communication, so that the rules of the content and relation being expressed can be recognised on its surface. By its permanent oscillation between semiotics and de-semiotics, between the ambiguity of the content, clarification of the relation and vice versa, the producer of the lie creates a polysemic space on multiple levels, a swampy land, an area of quicksand, where the recipient shall exit from only by wasting a lot of time. But what is it that keeps the recipient stay put, what makes him linger, to consume the meanings as the liar provides to him, thus participating directly and immediately to forming the lie? The 
answer is: first of all, the lack of information or, more exactly, the need for information. That who has been lied discovers the information as epistemological impasse and as paradox: he gets it without requesting it, he gets it without seeking it and uses it without verifying it.

The great test for him is to give a liar right. Actually, as J.-N. Kapferer shows, verifying the information is not something self-evident, because the "social knowledge is based on trust and not on evidence". The lie is based on the lack of inspection. The Pascal-Kapferer Law is, above all, a law of lie. The liar succeeds, because that who has been lied to does not verify the information: he lives it. Noting that the "invention" provides him with comfort, safety and success, the individual perseveres in this regard, reiterating or perfecting the formula of hiding (Balaban, 2005; Balaban, 2009; Cace, Cace, Cojocaru \& Sfetcu, 2013) .

The lie has a ubiquitous presence. It is a figure of rationality performed order to fâ difficulties and in the perspective of its resolution for the benefit of the ag nt ph gating The lie is always motivated, over-determined by wishes, interests. It nas an in mer al colouring; it is a path of easily achieving the goal. One lies for the mo variou asons of the desire to attack someone, to exonerate, to valorise, to hide shynes of to to to bring pleasure, to solve the pressures and norms of the commur ty. Lie $a_{1}$ ars $g$ all levels of the society. Montaigne said that the lie and stubbornness de e in childre ong with their body.

The lie relates both to different chronological res, and to individual's state of normality or abnormality. Children's lie would hay "as prime cause the adults' facility to deceive them when they are still very small, in order calm them down". They lie to get what has been prohibited to them, in order to avoid a reb or to giy the impression they do not deserve it, they lie out of jealousy or cowandice, of plan satisfy their vanity (attributing merits and importance to themselves).

The lie loses its innocence, as C. Lom ros anderstand, along with the child's transformation into an adult. The lattor as a " $\mathrm{b}$ child, develops and diversifies the truthless speech, the causes remaining the sam Lombro oy1992, p. 119). The lie increases along with the social body. Passing throy ario s forms - rumour, disinformation, propaganda - the lie makes its presence felt in ar po pecu... olitical, media, daily, etc. The best current world, of the two possible, fic s against suasion, especially against false communication, but reluctantly, which co ad vince us, does not persuade (cheat, fool, lie, manipulate, etc.),

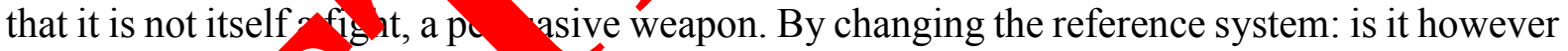
necessary to bl ck speech - we of of attack and defence, even to produce happiness? Where would the ro "ntic and "Romanian dream" go then? The "truthless" language officiates, even establish area literature (Buller \& Burgoon, 1994; Buller \& Burgoon, 1996; Burgo Qin, 66; surgoon \& Buller, 2008). For the language creating function, the unt th is means increasing the expressivity. The imprecision of words, the random stru e grammar are means to hide. For example, poetry lives through what is not said in

To Means to expire. But any literary text incites to readers' cooperation to "fill the gaps". The rie is facilitated by language The language we possess does not always lead us to truth or is it able to bear and circulate it. The word sequences the reality, it cuts it, rebuilds it according to laws other than its intrinsic ones. "All descriptions are partial. We do not really speak the truth; we fragment to rebuild desired alternatives, we select and avoid. We do not affirm "what exists", but what it could be" (Steiner R., 1983, p. 269).

The lie is mostly the work of language. Although it seems that the lie mainly represents a stratagem of thinking, things are actually the opposite: the stratagem of thinking is directed by a pre-eminent intrinsic language stratagem. According to G. Steiner, the human language 
has an inherently "misleading" structure (Steiner R., 1983, p. 268). This easily enables thinking to manifest deceitfully. Language forces into lying. Vladimir Jankelevitch is on an opposite position, whom in "Le Mensonge", reasons that lies reflect "the language impotence before the supreme richness of thinking" (Apud Steiner, 1983, p. 273). The truth is that a thinking that would incline towards lie finds in language an ally with a land propension towards ambiguity and lie.

Truthless communication is done exactly on the field of present. On it's field, here and now. The lie may aim the manipulative, distorting information. Through the lie, "information" of various types are promoted, which are attracted into various devices which exalt artain orientations or directions in the advantage of an idea or social group (parties, form ations, It occurs as a systematic activity to propagate messages, from positions interests practically determined groups, with the obligation to form certain opinion at . es, viey which would serve the interests of the groups. For example, as interven on, propa da $j$ a political lie.

According to G. Le Bon, the lie is based on a grammar of tic persu ion on a field with four parameters: the prestige of the source, the "rudite" a "mati on without evidence, the mental influence (Apud Buzărnescu, 1996, p.

In terms of cogitation, the lie is a complex psychic ac it sh signs that the distance between the real and the unreal is adjustable by sem mechan. It is a particularly complex behavioural act, which involves all compo ents of personali $y$ : thinking, language, affectivity, will, attention, etc.

As Constantin Cucoş shows (Cucoş, 2002, p 1), the cy unterfactual speech implies above all structuring a purpose given as an imaginary $h$, the act of lying subtends three ideas: a) a certain projective, ideational cap aich goes beyond the present; b) knowing the truth and refraining to say it; c) effective $\mathrm{V}$ fr $\mathrm{g}$ the advantage and knowing more
than another subject, being one sten ahead of $\mathrm{g}$.

Axiologically, the lie is a sign $t^{1}$ at $\mathrm{n}$ is a be $\mathrm{g}$ dissatisfied by what he is or what he has. Moreover, the lie is also requ by to ecivilisa ion factor. The society establishes a series of norms that must be comr on andividuals may elude them through a tacitly accepted lie. In this cas the lie is as "quasi-legalised evasion" (Cojocaru, 2009; Gorun, 2010; Cojocaru \& Co ocà 2012; Co. caru \& Popa, 2013).

Psychologic ly the li a protective, adaptive and successive strategy of inserting the individual into ne complicated clal network. Cognitively, it does not oppose so vehemently to the truth pure seness coes. Conversely, it is a form of refused, truncated truth, "of unbelievable' rough $s$ te. Thus, the (hidden) purpose of the lying agent primes, and not the cor nce on the futh or the falseness. The fictive frame not only replaces the reality, but also ansform 1 . The reality does not matter anymore, what we believe is beyond it (Co, aru hne. Cgjocaru, 2009; Cojocaru, 2010; Grosu, 2009; Traistaru \& Avram, 2014).

most mequent lies are driven by the verbal language, often betrayed by mimicry or gestures. Hands or face are more sincere, more transparent. We lie gesticulating, laughing, staring, in ariating, enjoying... lying ourselves. One can lie through mimicry, gestures, behaviour. The cruellest lies are often told in silence. A man could have stayed for hours without opening his mouth and yet to have been a disloyal friend or a pathetic slanderer.

By various strategies, the truthless show seeks to determine the effective consumer of the speech to become the effective consumer of subsidiary ideas (Unguru, 2010). The truthless speech concertedly acts both on the linguistic component and on its iconic component, of gestural image. The assembly of staging is entirely fictive even when all appearances tend towards real, because the figure of the lie capitalises the ambiguity to the maximum, the 
irrepressible mixture between appearance and essence. Discursive production transposes the logically decidable and difficult content into a connotative language, thus making more difficult the task of that who seeks the truth of what has been stated, bears the disability which the society creates as automatism through the inertia of grounding it on good faith and not strictly on evidence. It is certain that an individual who would verify all we say and all that emerges from our phrases might seem improper, according to L. Wittgenstein "the sentence affirms any phrase arising from it" (Wittgenstein L, 1991, p. 54). G. Durandin, specialist in the study of the lie, has shown that "often, what we declare rather reflects our thinking automatisms than what we have truly seen" (Apud Kapferer, 1993, p. 54).

The second constitutive condition of the lie, after substitutability, is intent onality. confused intention cancels the possibility of lie. There are explicit intentio and impli intentions. The real lie is part of the circuit of the latter. Recognising the in antio nakes t issue of lie undecidable, and, on the other hand, it constrains the consume to make c ecty es on intentionality and sincerity (Sandu, 2009; Cojocaru, Cojocaru \& inea, J 0; Po ca \& Sandu, 2010; Sandu, 2013).

Values are the model, object of lie. They are deeply onfused a inte cional and substitutable. The values of good, truth, beauty, freedom, hon an neither th nor false. One may say that values are confused. They cannot be the objec of den strability. The confused core of value feeds the lie. Any lie keeps a value captiy s. the lio special respect for values. Also, opinions generally related to options and axiologic decisions do not decide absolutely the truth or the false.

Opinions are highly subjective, just like valu Opinion provides a large part of its content of significations to deniability. Oninion sec the ideal place of the lie. Meanwhile, the perfect object of opinion is 4 ny honest opinion is a view. One may lie by exposing certain opinions the intention ity or ich not directed by the idea of authenticity and truthfulness. Other lies are cre led by displaying a false intentionality. When opinions are crossed by beliefs a a co ctions, e/lie is in difficulty, because its intentionality is vitiated. The beliefs and co tions cannot be fully surrendered to the illegitimate approach to substitute the reality wit do (Tran \& Vasilescu, 2003; Oprea, 2009; Oprea, Braunack-Mayer, Roge \& Stocks, 10)

In any case, th be loads a ti, which the opinion cannot access. Conviction has a firmness which ple it outs the preferences of the truthless speech. Firm convictions are a guard against ly

It is a 's na gl disease to believe he possesses the truth directly; and hence it results he is always on to de $y$ all that seems incomprehensible to him; although he only and natural ows the $\mathrm{e}$, and only takes as true those things the contrary of which appears to b $n$ as se (Frun , 2011; Cace, Arpinte, Cace \& Cojocaru, 2012; Caras \& Sandu, 2013). $\mathrm{Ve}$. somet unconsciously. We lie interestedly or unreasonably, guilty or innocently, openly or secretly. Je by falsifying or we lie... confirming (Cucoş C., 2002, p. 13). In the case of a lie (communicational operation of persuasive type), the overall intentionality is reaching a purpose, current intentionality is the frame (a chase, a class, a party), and reactive intentionality is the effective response in the context of discussions. The language, fiction or lie are classified by J. Austin as being acts of parasitic language. According to J. Searle, the lie and fiction are two language activities generally adopting the assertion or affirmation form, without actually being authentic assertions or affirmations. Actually, the rules dominating the success or failure of the assertion act are not complied with within fiction or lie: in both cases, the condition of sincerity (according to which the speaker believes in the veracity of his words) is breached. 
The speaker of a lie or of fiction text does not believe the veracity of his words (Frunză, 2013; Counsell \& Popova, 2000; Frunză, 2014). Thus, the intentions behind the lie and fiction are different intentions and, despite an apparent similarity, the lie and the fiction must not be mistaken, contrary to certain ideas. In case of fiction, the speaker pretends they do an act of assertion and therefore has the intention to pretend they do an act of assertion but has not the intention to deceive the interlocutor.

In other words, the speaker of a fiction shall pretend they are doing an act of assertion, but shall not try to make their interlocutor believe the latter is facing an authentic act of assertion, while the speaker of a lie shall pretend they are doing an act of assertion and shall try to make their interlocutor believe the latter is facing an authentic act of asse $110 \mathrm{n}$. S adds another dimension to his theory on fiction: he properly notes that not phrases 0 fiction text are false. But, by insisting on the coexistence of fiction and per assertic phrases within the same texts, he rejects this possibility. More precisely, c ie cannot $\mathrm{s}$. rst $\mathrm{nd}$ how fiction cannot deceive its interlocutor and it seems that Searle's ty ory fa to nro de an answer on this significant matter.

Let us take into account what type of act the lie is: it goes w nout say is a ocutionary act, but is it an illocutionary act or a perlocutionary act? If it is 1 cutionary the speaker's intentions must be expressed conventionally within the tatem. Actually, an obvious condition for the success of a deception act is for this a to seem an illocutionary act. Is it a perlocutionary act? Effecti ely, it seems that ne lie falls well within the scheme which Austin assigns to perlocutionary a s.

Moreover, it is a matter of convention here: the locution ry act is directly achieved by producing a phrase and not directly as an illocutionary any perlocutionary act, the lie is done by means of an illocutionary act and, cnecific case, by means of an illocutionary act of assertion. Or, if the condition of sincer is ar $\mathbb{A}$, then performed act cannot be a lie, because by definition, the speaker doas not bel ve the veracity of his words within a lie. Thus, the lie can only be "fulfilled" if perl hed act san authentic act of assertion, but if it is an authentic act of assertion, it is long a lie.

\section{CONCLUSION}

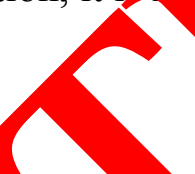

Any trutb ess sneech has owerful motivation. The object of lying is always something to be taken to acc nt:ppimons, beliefs, considerations, attitudes, facts, acts, etc. Their specificity is th pability o be replaced: substitutability. Non-substitutable things block the lie, are proa le abjects of the truthless speech.

The on-subs, able thing does not accept the ambiguity and confusion; the truthless lans on only be applied on unclear targets. The lie arises "from" and de ops "a confused language and a confused thinking.

\section{ACKNOWLEDGMENT}

This work was partially supported by the grant number 33C/2014, awarded in the internal grant competition of the University of Craiova. 


\section{References}

[1] R. Steiner (1983). După Babel. Bucureşti: Editura Univers.

[2] F. Nietzsche, (1998). Su verità e menzogna in senso extramorale. Napoli: Filema.

[3] A. Borowski, International Letters of Social and Humanistic Sciences 14 (2014) 7-17.

[4] S. Ponea, A. Sandu (2010). Assessment of Professional Competences. Constructive Dimension of Human Resources Management. Revista Românească pentru Educaţie Multidimensională.

[5] P. Bosun, V. Modrak, International Letters of Social and Humanistic Scien ss 14 (201 66-72.

[6] S. Ponea, A. Plugaru (2010). Evaluation of supervision practice of the social ser provided to elderly in Home Care Centre. Postmodern Openings

[7] Janusz Grabara, Michal Kolcun, Sebastian Kot (2014). The in transport logistics. International.

[8] S. Cojocaru (2010). Challenges in using mix methods is yaluc. Postmodern Openings.

[9] A. Borowski, International Letters of Social and Humanistic Sciences 3 (2013) 69-74.

[10] F. Nietzsche (2000). Volontà di potenţa. Milan Bompiani

[11] L. Oprea, Revista Română de Bioetică (2009)

[12] A. Sandu (2009). Tehnici afirmativ-apr piatı_ciopedagogie a succesului. Lumen.

[13] Ş. Buzărnescu (1996). Socioloropiniel ublice. Bucureşti: Editura Didactică şi Pedagogică.

[14] V. Tonoiu (1995). Omyro ggo Ducureçr: Editura Fundaţiei Culturale Române.

[15] D. Cojocaru, A. Sa du, S. Co, ru, Journal for the Study of Religions and Ideologies 28 (2011) 65-83

[16] D. L. Avrige Revista Sociologie 2 (2009) 47-60.

[17] D. Bote at, L. Grea, R. Il cscu, Revista Romana de Bioetica 11(4) (2013).

[18] D. C. Bà (2005) Comunicare publicitară. Cluj-Napoca: Accent.

[19] (201) vi g. Moral choice in public and private life. Random House LLC.

[20, C. Doaru. Inlernational Journal of Environmental Studies 65(4) (2008) 515-527.

[21] S. unză (2013). Ethical Communication and Social Responsibility. LAP Lambert Acau Mc Publishing.

[22] D. Cojocaru, R. P. Popa, Revista Romana de Bioetica 11(4) (2013).

[23] D. Bulgaru-Iliescu, L. Oprea, D. Cojocaru, A. Sandu, (2013). The Chronic Care Model (CCM) and the Social Gradient in Health. Revista de Cercetare şi Intervenţie Socială.

[24] S. Frunză (2011). Comunicare etică şi responsabilitate socială. Bucureşti: Tritonic.

[25] Marian Siminică, Autrelia Traistaru (2013). Self-Directed Learning in Economic Education. International. 
[26] S. Frunză, Revista de cercetare şi intervenţie socială 32 (2011) 155-171.

[27] A. Borowski, International Letters of Social and Humanistic Sciences 3 (2013) 69-74.

[28] D. B. Buller, J. K. Burgoon, Communication theory 6(3) (1996) 203-242.

[29] Aurelia Traistaru, Marioara Avram, International Letters of Social and Humanistic Sciences 13 (2014) 79-88.

[30] J. K. Burgoon, D. B. Buller, Engaging theories in interpersonal communication: Multiple perspectives (2008) 227-239.

[31] S. Cojocaru, Revista de cercetare şi intervenţie socială 24 (2009) 41-71.

[32] A. Borowski, International Letters of Social and Humanistic Sciences 6(2) 86-90.

[33] D. Cojocaru, S. Cojocaru, La revue internationale de l'éducation fo niliale 2 (_ 81-94.

[34] Gorun A. coordonator, Jinaru Aron, Niculescu George, Car salu dru, C agea Smaranda (2010). Recadrări transdisciplinare. Un deme calizat pa rarea antreprenorială în turismul cultural. Editura Academi a Bı uşi, Târg -Jiu.

[35] S. Cojocaru, D. Cojocaru, O. Bunea, Social Resea froports N or0) 3-87.

[36] A. Borowski, International Letters of Social ar Humanistic Sciences 14 (2014) 33-41.

[37] Janusz Grabara, Petre Bosun, International Lea of Social and Humanistic Sciences 14 (2014) 59-65.

[38] Paula Bajdor, Iwona Grabara, (2014). 1 Information System Flows in Fulfilling Customers' Individual Orders Joynar.

[39] D. Cojocaru, Revista de Cer coni Inter entie Socială 26 (2009) 87-98.

[40] J. Popova, Journal of Dar ian mudies and Research 3(1) (2013).

[41] A. Borowski, Intery tional L of Social and Humanistic Sciences 11 (2014) 1-168.

[42] C. Cucoş (2002 Mu ună, cont, facere, simulare. Iaşi: Editura Polirom.

[43] V. Tabără (202). Dezvo reg capacităţii administrative. Bucureşti: Editura CH Beck.

[44] A. Car A. Sa y, Journal of Social Work Practice (ahead-of-print) (2013) 1-20.

[45] Balaban \ (2009) Publicitatea: de la planificarea strategică la implementarea

Polin
[47] A. B Wski, International Letters of Social and Humanistic Sciences 2 (2014)
110-121.

[48] J. K. Burgoon, T. Qin, Journal of Language and Social Psychology 25(1) (2006) 76-96.

[49] F. Hristea, M. Colhon, Fundamenta Informaticae Journal 119(1) (2012) 61-86.

[50] S. Cojocaru, Revista de Cercetare şi Intervenţie Socială 29 (2010) 72-91.

[51] Sandu Frunză (2014). Advertising and Administration under the Pressure of Ethics. Les Arcs: Editions de la Suers. 
[52] A. Borowski, International Letters of Social and Humanistic Sciences 4 (2013) 70-74.

[53] D. C. Balaban, C. M. Băltăreţu Journal of Media Research-Revista de Studii Media 1(6) (2010) 67-74.

[54] C. Cace, S. Cace, S. Cojocaru, L. Sfetcu (2013). Social Economy in RomaniaChallenges and Perspectives. Transylvanian.

[55] E. Unguru (2010). Features of lie in verbal and nonverbal communication/ Trăsături ale minciunii în comunicarea verbală şi non-verbală. Postmodern Openings.

[56] L. Oprea, A. Braunack-Mayer, W. A. Rogers, N. Stocks (2010). An ethical for the Chronic Care Model (CCM). Health Expectations.

[57] Rajesh K. Yadav, International Letters of Social and Humanistic Scie es 84-90.

[58] Jacek Tittenbrun, International Letters of Social and Humanistac en es (2 14) 26-48.

[59] S. Cace, D. Arpinte, C. Cace, D. Cojocaru (2012). Fing ch Pesources magement Factor of Sustenable Development of the NGO' Implenting cial Economy activities. Transylvanian.

[60] Jason L. Powell, International Letters of Socia and Humanistic Sciences 7 (2014) 22-30.

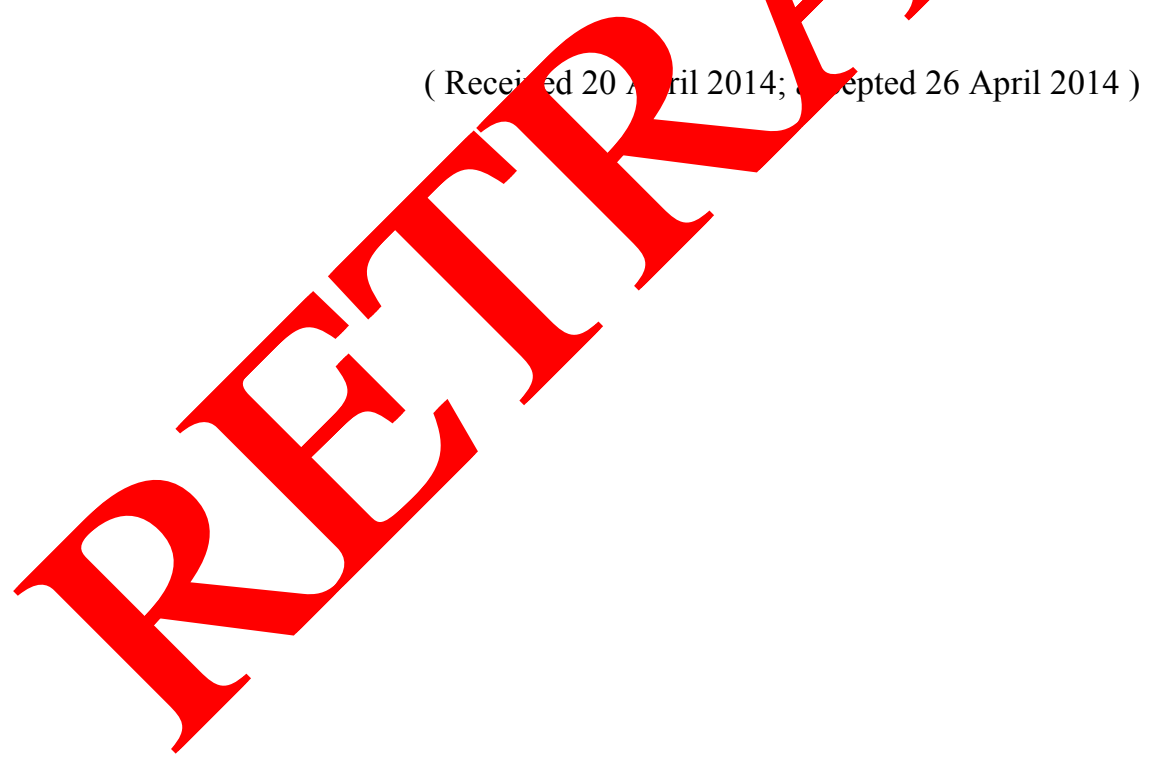

